\title{
The Determinants of Capital Structure: Evidence from Selected Listed Companies in Sri Lanka
}

\author{
Tharmalingam Pratheepan ${ }^{1} \&$ Y. K. Weerakoon Banda ${ }^{2}$ \\ ${ }^{1}$ Department of Finance \& Accountancy, Vavuniya Campus of the University of Jaffna, Sri Lanka \\ ${ }^{2}$ Department of Finance, University of Sri Jayewardenepura, Sri Lanka \\ Correspondence: Tharmalingam Pratheepan, Department of Finance \& Accountancy, Vavuniya Campus of the \\ University of Jaffna, Sri Lanka. Tel: 947-7949-1019. E-mail: ttpratheepan@ yahoo.com
}

Received: January 2, 2016

Accepted: January 23, 2016

Online Published: January 25, 2016

doi:10.5539/ijef.v8n2p94

URL: http://dx.doi.org/10.5539/ijef.v8n2p94

\begin{abstract}
This research examines the determinants of capital structure of selected listed companies in Sri Lanka. The capital structure of 55 companies listed in Colombo Stock Exchange (CSE) is empirically examined using the fixed effects model. Based on the findings of the panel data analysis during the period of 2003-2012, Profitability exhibits statistically significant of inverse relationship with leverage while firm size and growth shows statistically significant of positive relationship with leverage for selected listed companies in Sri Lanka. Non-debt tax shields and tangibility indicate insignificant impacts on leverage. The results of this empirical study shows that there is robust evidence to support the pecking order theory by manufacturing based companies on the capital structure determinant of profitability variable, and growth variable also strongly supports to the association of the pecking order theory. Though, trade-off theory also can not be rejected because of the correct estimate of the positive sign of size variable of manufacturing based companies. Thus, implication of pecking order theory is more appropriate in Sri Lankan perspective.
\end{abstract}

Keywords: capital structure, determinants, leverage and panel data

\section{Introduction}

A growing company needs capital. This capital can be collected from debt or equity. When companies can finance themselves with either debt or equity, certain questions arise. Is one better than the other? If so, should firms be financed with all debt or all equity? Suppose that the best solution is some combination of debt and equity, what is the optimal mix? Easily we can say that the optimal capital structure of a firm is the composition of debt and equity which results in the minimum cost of capital.

Capital structure is important for the survival in the industry, growth and performance of the firm. There has been a growing concern worldwide in detecting the variables associated with debt leverage (Voulgaris, Asteriou, \& Agiomirgianakis, 2004).

The combination of debt and equity (the decision of capital structure) is one of the most essential financial policy level decisions, and one of the widely researched aspects in corporate finance, but decisions regarding capital structure are crucial for every business and manufacturing companies. In the corporate form of business, generally it is the task of the top management to take capital structure decisions in a way that to increase the firm value. Though, maximization of firm value is not an easy task since it involves the selection of debt and equity securities in a balanced proportion keeping in view of different various costs and benefits connected with these securities. The inappropriate decision in the selection method of securities may lead the firm to financial distress as well as the bankruptcy.

Many empirical studies have been completed on determinant factors of capital structure and such determinants are well documented in many other countries such as UK, Greece, Qatar, Turkic, Ghana, Australia, Pakistan, Indonesia, Brazil, India, and etc. However, comprehensive studies to measure the determinants of capital structure are still in its infancy and not much available in Sri Lankan context by using the panel data analysis. Therefore, this research may fill the knowledge gap with regard to this aspect. 


\section{Review of Literature}

\subsection{Theoretical Review}

\subsubsection{The Modigliani and Miller Propositions}

The theory of capital structure was originally developed by Modigliani and Miller (1958). There are two major theories of capital structure which form basis of the paper. The first one is trade off theory and second one is pecking order theory. Therefore, theoretical principles underlying the financing, capital structure and lending choices of firms can be explained either in terms of a static trade-off theory or pecking order theory. The static trade - off theory explains various aspects, such as the exposure of the firm to insolvency and agency cost in contradiction of tax benefits associated with usage of debt (Amidu, 2007).

Modigliani and Miller (1958) remained as the pioneers in hypothetically examining and algebraically representing the effect of capital structure on firm value. They suppose that perfect capital markets, and they came up with the broadly well-known concept of "capital structure irrelevance", it means that the capital structure decisions that a firm takes does not have any impact on its value. Subsequently, many researchers, including Modigliani and Miller, investigated the effects of less restrictive assumptions on the association between capital structure decision and the value of the firm.

\subsubsection{Trade-Off Theory}

The trade-off theory is developed from the models established on taxes and agency cost. Modigliani and Miller (1963), and Jensen and Meckling (1976) DeAngelo and Masulis (1980) posit that the firm has an optimum capital structure by balancing the benefits of debt and the cost of debt. Miller (1977) distinguishes three tax rates in the tax legislation of the USA that determine the firm's value. Those are the rate of corporate tax, the tax rate imposed on the dividend income and the tax rate imposed on the interest income. Further Miller reported that the value of the firm depends on the relative amount of each tax rate, related with the other two.

\subsubsection{Pecking Order Theory}

The idea of asymmetric information in determining the optimum capital structure is primarily stated by Myers (1984) and Myers and Majluf (1984). They focus on the information asymmetries between firm insiders and outsiders. They anticipated that managers take decisions in order to increase the wealth of current shareholders. Hence, they avoid delivering underestimated stock unless the value move from existing shareholders to new shareholders is more than balanced by the net present value of the growth opportunity. It will lead to the decision that new shares will only be delivered at a lesser price than that required by the actual market value of the firm.

Hence, an announcement of new share issue is openly referred as a negative signal; it means that existing shareholders have overvalued shares. This negative signal effects in the stock price drop. Certainly, several studies have confirmed that the announcement of a stock issue have resulted in a decline of the stock price. That is why several firms are willing to implement the pecking order theory. The pecking order theory indicates that firms will primarily use inside generated funds, i.e. retained earnings, where there is no presence of information asymmetry, then they will draw debt capital if extra funds are required and lastly they will turn to new equity issue to fulfil any outstanding capital necessities. Therefore, highly profitable firms that make high profits are anticipated to use lower debt capital than those that are not very profitable. Several researches have been done to study the impact of profitability on leverage of the firm.

The notion of information asymmetry suggests that firms should maintain some reserve borrowing capacity which will allow them to get benefit of good investment opportunities by delivering debt if essential. Growth influences differences in the firm's value. Higher differences in the firm's value are frequently reported as larger risk. Because of this, a company that has significant growth opportunities is measured as a more risky company and faces problems in rising debt with positive terms. So, it employs fewer debts in its capital structure. On the other hand, the cash flows of a company which amount is most probable to stay constant in the forthcoming are expectable and its capital necessities can be funded with loan more simply than these of a company with growth opportunities.

Titman and Wessels (1988) examined different models that describe capital structure alternatives, by involving all hypotheses together in the empirical test; they posit more confidence in the pecking than the target adjustment model.

\subsection{Empirical Review}

A lot of discussion whether or not an optimum capital structure even available is raised among academicians. An important concern for researchers is to identify the factors that influence the capital structure position of a firm. 
Generally, a capital structure of the firm was represented by financial leverage. There is no perfect definition of financial leverage in the previous empirical studies and the specific choices depend on the purposes of the study (Rajan \& Zingales, 1995). Myers and Majluf (1984) who defined the pecking order theory, argue that firms favour interior funds to exterior funds and that when external funds are the only option, firms tend to prefer debt over equity. Samarakoon (1999) examined the capital structure of Sri Lankan companies, indicates that the use of long term debt is relatively low in Sri Lankan listed companies, although companies prefer internal finance to external finance and straight debt to convertible debt.

According to the Amidu (2007), above the 87 percent of the assets of the banks are financed by debt and, except this, short term debts seem to establish more than three quarters of the capital of the banks. This indicates that the significance of short term debts above long term debts in financing of the Ghanaian banks. Eldomiaty (2007) opined that the statistically significant positive relationship of long term debt with total debt ratio, suggesting that company leverage changes positively according to the changes of long term debt.

Upneya and Dalcor (2001) Indicate that oldest firms have higher total and long term debt. This indicates slightly contrary to their anticipation, but may be due to huge capital expenditure plans. In the other way round, oldest and more cost-effective firms with more cash flows do not want long-term debt. As usual, firms usage only 30 percent debt capital in their capital structure, one clarification is that Jordanian firms manage to reduce the probability of bankruptcy by decreasing the debt capital reported by Al-Najjar and Tayer (2008).

According to the Santi (2003), Indonesian firms employ relatively high debt in their capital structure, around $53 \%, 15 \%$, and $38 \%$ for total debt, long term debt, and short term debt respectively. He mention that these ratios increase during the crisis period and Indonesian economy faced a downturn since 1997 as well as at the beginning of 1997s, Indonesian firms faced the decreased in their equity values due to exchange rate swing. Abor (2007) opined that small and medium enterprises in Ghana's capital structures differ within industries and that industries with great collateral value are frequently capable of inviting further long term debt. Moreover, he mentions that the agriculture industry seems to have the maximum asset structure or collateral and, therefore, exhibits the higher long term debt ratio. This indicates the significance of collateral in retrieving long term debt.

Abor and Biekpe (2009) shows that short-term debt forms a comparatively high percentage of total debt of small and medium enterprises (SMEs) in Ghana. This suggests that long term leverage represents about 5.74 percent of the capital of SMEs while short term debt represents about 36.26 percent of total assets, underlining the significance of short term debt throughout long term debt in financing Ghanaian SMEs.

Qiu and La (2010) reported that, generally, indebted firms are five times bigger than firms that use equity for financing in Australia. In addition, they mention that both listed and unlisted small firms, are lower reliant on long term debt due to the restricted access to capital market and more transaction costs of issuing debt securities, they conclude that a substantial amount of Australian firms do not willing to use debt and these firms are usually smaller, less profitable and more uncertain than indebted firms.

According to the Fauzi et al. (2013), the most of the firms located in New Zealand, financing was made by issuing debt securities, specifically short term financing due to the New Zealand firms generally, small and medium enterprises and the most of the New Zealand firms were in the primary sector. They emphasize that however, New Zealand is reflected a developed market, New Zealand's business characteristics vary from other developed countries, and hence may result in the dissimilar funding alternatives. Forte, Barros and Nakumura (2013) state that capital structure is very insistent in small and medium sized Brazilian enterprises. Certainly, lagged leverage is the appropriate interpreter of consequent leverage in whole regressions.

\section{Development of Hypothesis}

The major objective of this study is to estimate the relative importance of factors affecting Sri Lankan listed companies' choice of capital structure. Capital structure theories and empirical findings identify a number of variables that influence a firm's debt position in the context of Sri Lankan listed companies.

In choosing the explanatory variables to be used in the analysis of cross sectional variation in capital structure is filled with difficulties (Titman \& wessels, 1988). After reviewing the available empirical literature on capital structure determinants, five key independent variables have been identified as the most used to explain capital structure alternatives. To examine the association between capital structure determinants and capital structure, we make the hypothesis as below:

\subsection{Firm Size}

Firm size is generally used as a hypothetical determinant of capital structure choices (Rajan \& Zingales, 1995; 
Titman \& Wessels, 1988). Noulas and Genimakis (2011), Mei qiu and Bo la (2010), and Mallikarjunappa and Goveas (2007) said that firm size is an insignificant determinant of capital structure choice. However, empirical studies have found mixed results of the effect of firm size on capital structure, for example, Wald (1999), Wiwattanakantang (1999), Santi (2003), Bayrakdaroglu et al. (2013) and Forte et al. (2013) showed a positive sign for the association between the firm size and leverage ratios. Though, the studies by Titman and Wessels (1988), Ooi (1999) observe negative association between the firm size and leverage.

$\mathrm{H}_{1}$ : Firm size has a significant effect on leverage.

\subsection{Profitability}

The association between firm's profitability and capital structure may be defined by the pecking order theory propositioned by Myers and Majluf (1984).

Ooi (1999), and Mallikarjunappa and Goveas (2007) show that insignificant relationship between the profitability and leverage ratios, even though Qiu and La (2010), Noulas and Genimakis (2011) and Bayrakdaroglu et al. (2013) reported a statically negative significant relation between the profitability and leverage.

$\mathrm{H}_{2}$ : Profitability has a significant effect on leverage.

\subsection{Growth}

Generally the firms that have knowledge of high growth rates frequently want more aggressive funding. Morri and Cristanziani (2009), ooi (1999), and Mallikarjunappa and Goveas (2007) show insignificant relationship between growth and leverage. However, empirical studies have mixed results of the growth and leverage, for example, Gwatidzo and Ramjee (2012), Ameer (2013) and Bayrakdaroglu et al. (2013) find a positive relation between growth and leverage while abbad and zaluki (2012), Gurcharan (2010) and Antoniou et al. (2008) show negative association between growth and leverage.

$\mathrm{H}_{3}$ : Growth has a significant effect on leverage.

\subsection{Tangibility}

Structure of assets should be a one of the factor for capital structure decisions. Firms may utilise tangible assets as collateral in order to give more access to credit or diminishing its cost.

Abbad and Zaluki (2012) found the positive association between asset structure and total debt ratio but it is not significant. Empirical studies have found mixed results of the effect of tangibility on leverage. Mukherjee and Mahakud (2012), Gwatidzo and Ramjee (2012) and Chiang et al. (2010) reported a positive sign for the relation between the tangibility and leverage. However, the studies by Bayrakdaroglu et al. (2013), smith (2012) and Noulas and Genimakis (2011) posit a significant negative association between tangibility and growth.

$\mathrm{H}_{4}$ : The tangibility has a significant effect on leverage.

\subsection{Non-Debt Tax Shield}

There is an argument that firms with good performance in the past years, have less default risk with more debt capacity. Thus, they can obtain more leverage to exploit the tax-shield advantage of debt (Forte et al., 2013).

Titman and Wessels (1988) have reported that there is no effect on debt ratios occurring from Non-debt tax shields. Akhtar (2005) also provides empirical evidence of the insignificant coefficient on the non-debt tax shields. Even though Mukherjee and Mahakud (2012), Bayrakdaroglu et al. (2013) and Antoniou et al. (2008) show a positive association between Non-debt tax shield and leverage, Gurcharan (2010), Wald (1999) and Wiwattanakantang (1999) find the negative relation between Non-debt tax shield and leverage.

$\mathrm{H}_{5}$ : The Non-debt tax shield has a significant effect on leverage.

\section{Conceptual Framework}

Review of literature identified the variables affecting the capital structure of the manufacturing companies and it has been referred as firm-specific factors. According to the review of literature, this study can present the association between explanatory variables and response variable as follows. 


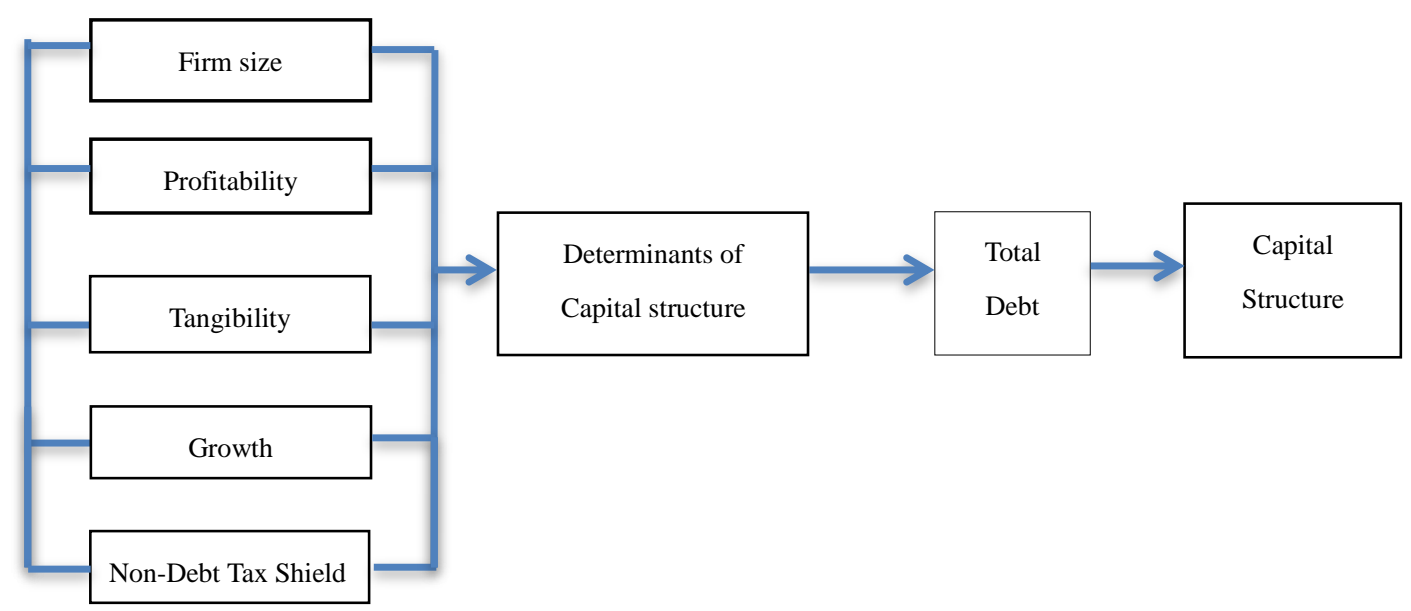

Figure 1. Diagrammatic depiction between dependent and independent variables

\section{Research Methodology}

\subsection{Study Area, Data Collection, and Sources of Data}

For the purpose of this study, the population has been defined in terms of the number of companies listed in Colombo stock exchange (CSE) for the period from 2003 to 2012. During this period, the total number of such companies falling in twenty different sectors is around 287. They are Banking and Finance, Beverage food and tobacco, Chemicals and pharmaceuticals, Construction and engineering, Diversified holdings, Footware and textile, Health care, Hotels and travels, Information technology, Investment trusts, Closed end funds, Land and property, Manufacturing, Motors, Oil palms, Plantations, Power and energy, Services, Stores and supplies, Telecommunications and trading.

This study uses the data from the annual report of Sri Lankan listed firms for the period of 2003-2012 collected from Colombo Stock Exchange (CSE). Further, these data was taken from audited accounts (i.e., comprehensive income statement and statement of financial position) of the particular companies as honestly accurate and reliable.

\subsection{Model Estimation and Specification}

This study employs the panel data analysis that allows the unobservable heterogeneity for each observation contained in the sample to be removed and multicollinearity among independent variables to be alleviated. There are some issues that might be occurring in the regression model such as heteroskedasticity and multicollinearity problems. Those issues may produce inconsistency of the estimation of Ordinary least squares (OLS).

The data for this analysis used the cross sectional and time series data (strongly balanced panel data) for fifty five companies during the period from 2003 to 2012.

In order to associate cross-sectional with time series data and formulate the characteristics of the market, pooling methods were used for the panel data. The models for the panel data are more useful research tools, which give the researcher the capability to take in to account any kind of effect that the cross-sectional data may have, and finally to estimate the suitable empirical model. A overall model for the panel data permits the researcher to empirically estimate the association between dependent and independent variables with more flexibility. (Eriotis et al., 2007).

The usage of panel data raises the sample size significantly and is more suitable to study the dynamics of change. For the purpose of estimating the effects of independent variables on the debt ratio (leverage), three estimation models were used such as pooled ordinary least squares (OLS), the random effects, and the fixed effects.

As panel data considered observations on the similar cross-sectional units over numerous time periods, there might be cross - sectional effects on each company or on a set of group of companies. Numerous methods are accessible to solve this type of issue though the fixed and random effects models in panel econometric techniques are more essential.

The fixed effects model considers the independence of each firms or cross-sectional unit incoporated in the sample by allowing the intercept vary for each company but still assumes that the slope coefficients are constant within the companies. The random effects model estimates the coefficients based on the assumption that the 
individual or group effects are uncorrelated with other independent variables and can be formulated.

Furthermore, this study applied the Hausman (1978) specification test to find out which estimation model, either fixed or random effects, best describes our estimation. Researcher used the Stata 12 software to analysis the data.

The explanation of three estimation models - pooled OLS, the fixed effects, and the random effects-is given below:

$$
\begin{aligned}
& \mathrm{DR}_{i t}=\beta_{0}+\beta_{1} \text { SIZE }_{i t}+\beta_{2} \text { PROF }_{i t}+\beta_{3} \text { GROW }_{i t}+\beta_{4} T A N G_{i t}+\beta_{5} N D T S_{i t}+\varepsilon_{i t} \\
& \mathrm{DR}_{i t}=\beta_{0}+\beta_{1} \text { SIZE }_{i t}+\beta_{2} \text { PROF }_{i t}+\beta_{3} \text { GROW }_{i t}+\beta_{4} T A N G_{i t}+\beta_{5} N D T S_{i t}+\mu_{i t} \\
& \mathrm{DR}_{i t}=\beta_{0}+\beta_{1} \text { SIZE }_{i t}+\beta_{2} \text { PROF }_{i t}+\beta_{3} \text { GROW }_{i t}+\beta_{4} T_{A N G}+\beta_{5} N D T S_{i t}+\varepsilon_{i t}+\mu_{i t}
\end{aligned}
$$

Where:

$\mathrm{DR}_{i t}=$ debt ratio of firm $i$ at time $t$.

$\mathrm{SIZE}_{i t}=$ size of firm $i$ at time $t$.

$\mathrm{PROF}_{i t}=$ profitability of firm $i$ at time $t$.

GROW $_{i t}=$ growth of firm $i$ at time $t$.

$\mathrm{TANG}_{i t}=$ tangibility of firm $i$ at time $t$.

NDTS $_{i t}=$ non-debt tax shields of firm $i$ at time $t$.

$\beta_{0}=$ Common - intercept .

$\beta_{1}-\beta_{5}=$ Coefficients of the concerned explanatory variables.

$\varepsilon_{i t}=$ Stochastic error term of firm $i$ at time $t$.

$\beta_{0 i}=y$-intercept of firm $i$.

$\mu_{i t}=$ error term of firm $i$ at time $t$.

$\varepsilon_{i}=$ cross-sectional error component.

\section{Empirical Results and Analysis}

This section represents the results of the study. Firstly, there is a brief general description of the summary statistics on the dependent and independent variables of capital structure, and it is followed by the analyses of measures of determinants of capital structure.

\subsection{Descriptive Statistics}

Table 2 presents the descriptive statistics for all variables such as response and explanatory variables. The descriptive statistics based on fifty five companies' ten years data set which includes five hundred and fifty observations, reflect the capital structures of the analysed firms.

Table 2. Descriptive statistics of the dependent and independent variables

\begin{tabular}{cccccc}
\hline Variable & Observations & Mean & Std. Dev. & Min & Max \\
\hline DR & 550 & 0.4387322 & 0.240506 & 0.0010445 & 0.9888351 \\
PROF & 550 & 0.1135179 & 0.1283976 & -0.5171878 & 0.9118637 \\
SIZE & 550 & 9.1084 & 0.9584551 & 0.0001 & 10.91788 \\
GROW & 550 & 1.591364 & 1.503673 & 0.02299 & 14.05246 \\
NDTS & 550 & 0.09586 & 0.1239491 & 0.0000319 & 1.70132 \\
TANG & 550 & 0.4801623 & 0.2149468 & 0.0269522 & 0.9956021 \\
\hline
\end{tabular}

Note. The summary statistics are based on the final sample of 550 firm-year observations. The dependent variable is debt ratio (DR). The regressors are Profitability (PROF), firm size (SIZE), growth opportunities (GROW), Non-debt tax shield (NDTS) and Tangibility (TANG). Source: Researchers Regression Result.

From Table 2 the debt ratio indicates 43.87 percent with a range of 0 to 0.99 indicating that all companies have leverage similar to the average leverage of industry. In addition, the average debt utilized by the Sri Lankan companies accounts for 43.87 percent which is similar to the range of the average total debt for many developed countries in the period of 1990 s. 
Average value of profitability over ten year period is 11.35 percent that demonstrates a less remarkable performance of the companies during the study period since minimum profitability is -51.71 percent. In addition, the average value for tangibility is 0.48 , showing that the most of the firms have moderate fixed assets, thus they are valuable for rising debt financing by using these fixed assets as collateral. Growth average value of 1.5913 indicates that the difference between book value and market value of the equity (Market to book ratio). Finally, Only 9 percent is depreciation on the total assets.

\subsection{The Correlation Matrix}

In order to examine the strength and relationships among the regressions, a correlation matrix of the variables for the sample firms is discussed in Table 3.

Table 3. Correlation matrix of the variables

\begin{tabular}{ccccccc}
\hline & DR & SIZE & PROF & GROW & TANG & NDTS \\
\hline DR & 1.0000 & & & & & \\
SIZE & 0.1941 & 1.0000 & & & & \\
& 0.0000 & & & & \\
PROF & -0.3205 & 0.3675 & 1.0000 & & & \\
& 0.0000 & 0.0000 & & & & \\
GROW & 0.6543 & 0.0363 & -0.3951 & 1.0000 & & \\
& 0.0000 & 0.3950 & 0.0000 & & & \\
TANG & 0.0236 & -0.1932 & -0.3754 & -0.0059 & 1.0000 & \\
& 0.5802 & 0.0000 & 0.0000 & 0.8904 & & \\
NDTS & -0.2693 & 0.0795 & 0.4338 & -0.3045 & -0.1652 & \\
& 0.0000 & 0.0623 & 0.0000 & 0.0000 & 0.0001 & \\
\hline
\end{tabular}

Note. The correlation presented in this matrix is based on 550 firm year observations. The significant parameters are representing the confidence levels of $99 \%$.

Table 3 presents correlation matrix for all the variables in the model. The highest correlation is between growth and debt ratio (leverage) at 0.6543 . This posits that firms with more debt financing tend to maximize the growth of the firm.

The correlation matrix also shows several significant relationships among the attributes. We find that firm size and tangibility are to be negatively related. Tangibility is also negatively associated with profitability as well as with growth, it is in the line with the opinion that firms with a high percentage of their worth accounted by tangible property assets have less growth opportunity. Table 3 also shows that big firms have a fewer property asset but they are highly engaged in property business and development undertakings. The higher profitability related with firm size is supported by their positive correlation, to increase the profitability, sales returns of companies are also higher, as denoted by positive association with profitability.

As expected, the firm size has positive relationship with growth. Conforming to their higher sales returns, firms also have higher expected growth. Companies engaged heavily in depreciation on fixed assets (non-debt tax shield) are also noted to have lower growth and the tangibility. Finally, the negative association between nondebt tax shield and tangibility is in the line with the view that depreciation has a considerable impact on the fixed asset to total asset ratio.

The size of the company has low positive correlation with the debt ratio (0.194) and it is statistically significant at $1 \%$ level. Profitability has negatively correlated with debt ratio while it has positive correlation with size of the company. Growth is positively correlated with size but statically not significant. Similarly tangibility and growth has inverse correlation but statistically not significant. Meanwhile the statistically not significant positive correlation is observed between the non-debt tax shield and the size of the company at 5\% level. Tangibility is negatively correlated with size, profitability and growth, however the negative correlation between tangibility and growth is not statistically significant.

\section{Regression Results}

For the estimation of the panel regression model, there are three different methods such as pooled ordinary least square method, fixed effects, and random effects models, and these models are important to determine the firm or country effects, time effects and certain factors of capital structure in the emergent market. 


\subsection{Ordinary Least Squares (OLS) Model}

In the hypothesis development, there are no groups or individual effects between the firms that incorporated in the sample, the pooled OLS model is estimated according to the first equation mentioned in the model estimation and specification.

Table 4. The effect of explanatory variables on the debt ratio $\left(\mathrm{DR}_{\mathrm{it}}\right)$ using the OLS estimation model

\begin{tabular}{lcccccr}
\hline \multicolumn{1}{c}{ Variables } & Coefficient & Std. Err. & t-statistic & P>t & [95\% Conf. & Interval] \\
\hline _Cons & -0.0286874 & 0.0794024 & -0.36 & 0.718 & -0.1846602 & 0.1272854 \\
SIZE & 0.0596186 & 0.0085423 & 6.98 & 0.000 & 0.0428387 & 0.0763985 \\
PROF & -0.3044227 & 0.0786215 & -3.87 & 0.000 & -0.4588616 & -0.1499839 \\
GROW & 0.0888059 & 0.0055169 & 16.1 & 0.000 & 0.0779689 & 0.099643 \\
TANG & 0.005159 & 0.0379207 & 0.14 & 0.892 & -0.06933 & 0.0796479 \\
NDTS & -0.0853059 & 0.0675157 & -1.26 & 0.207 & -0.217929 & 0.0473175 \\
\hline
\end{tabular}

Number of obs $=550 ;$ R-squared $=0.4818$; Adjusted R-squared $=0.4771$;

Prob $>\mathrm{F}=0.0000 ; \mathrm{F}(5,544)=101.17 ;$ Root MSE $=.17392$

Note. SIZE - firm size, PROF - Profitability, GROW - Growth, TANG - Tangibility, NDTS - non-debt tax shield.

From Table 4, firm size, profitability, and growth proved to be significant in confidence level of five percent. Non - debt tax shield is found insignificant while tangibility is found highly insignificant. The OLS regression has high adjusted R-squared and seems to be capable to describe differences in the debt ratio. Moreover, the F-statistics shows the significance of the OLS regression model.

Further, The Table 4 reveals that, the association between size of the firm and the debt ratio have positive relation and is statistically significant. The coefficient value of size of the firm is 0.0596 which represents that, when other independent variables are constant, one unit of size increase will lead to the 0.0596 unit increases in debt ratio.

Profitability shows the statistically significant negative relationship with the debt ratio. Further, increase of one unit of profitability will reduce 0.3044 units of debt ratio.

There is statistically significant positive relationship between growth and leverage. The coefficient value of the growth indicates that, increase of the one unit of growth will lead to raise the 0.0888 units of leverage.

Out of five explanatory variables, all three are statistically significant to influence on debt ratio of the firm except the two variables, tangibility and non-debt tax shield. On the other hand, out of these five explanatory variables, profitability and non-debt tax shield have negative relationship with debt ratio while other variables size, growth and tangibility have the positive relationship.

\subsection{Fixed Effect Models}

The second equation presented under the model estimation and specification is fit for fixed effects model.The fixed effect models assume that the coefficiencies are changed amongst the units and time. That indicates, the variations in the fixed effects decide the variations in behaviors of units, considering the slope coefficiencies as constant (Bayrakdaroglu et al., 2013). The model takes the individual effects of the firms as a fixed effect. So, In order to deduct the unobserved heterogeneity, fixed effects model is estimated.

Table 5. The effect of explanatory variables on the debt ratio $\left(\mathrm{DR}_{\mathrm{it}}\right)$ using the fixed effects estimation model

\begin{tabular}{lllllll}
\hline Variables & \multicolumn{1}{c}{ Coefficient. } & \multicolumn{1}{c}{ Std. Err. } & \multicolumn{1}{c}{$\mathrm{t}$} & $\mathrm{P}>\mathrm{t}$ & \multicolumn{1}{c}{ [95\% Conf. } & \multicolumn{1}{c}{ Interval] } \\
\hline C Cons & -0.064223 & 0.1231384 & -0.52 & 0.602 & -0.3061674 & 0.1777214 \\
SIZE & 0.0615993 & 0.011465 & 5.37 & 0.000 & 0.0390727 & 0.084126 \\
PROF & -0.2707124 & 0.0864916 & -3.13 & 0.002 & -0.4406526 & -0.1007723 \\
GROW & 0.0680292 & 0.00515 & 13.21 & 0.000 & 0.0579105 & 0.078148 \\
TANG & 0.0097144 & 0.0726928 & 0.13 & 0.894 & -0.1331137 & 0.1525424 \\
NDTS & -0.0518281 & 0.0587933 & -0.88 & 0.378 & -0.1673462 & 0.0636901 \\
\hline
\end{tabular}

Note. $\mathrm{R}$-sq: within $=0.3698$, between $=0.6227$, overall $=0.4774 ;$ corr $\left(\mathrm{u}_{-} \mathrm{i}, \mathrm{Xb}\right)=0.2721 ; \mathrm{F}(5,490)=57.51 ;$ Prob $>\mathrm{F}=0.0000$; sigma_u|.11781468; sigma_e |.14036692; rho |.41331115 (fraction of variance due to u_i). 
From Table 5, firm size, profitability, and growth proved to be significant in confidence level of five percent. Non-debt tax shield is found insignificant. Tangibility remained highly insignificant. Moreover, the coefficient is positive for firm size, growth and tangibility while negative for profitability and non-debt tax shield.

According to the Table 5, the coefficient for size of the company is 0.061 which shows that for a one unit increasing in size, debt ratio of the firm is expected to increase by 0.061 units holding other variables constant. The coefficient for Profitability is -0.27 which suggests that as profit increases by one unit, debt ratio reduces by 0.27 units holding other variables constant. Assuming that other factors are constant, one unit increase in growth will lead to an increase of debt ratio by 0.0680 units.

The correlations value between error terms and regressors (corr $\left(u_{-} i, X b\right)=0.2721$ ) shows that errors $U_{i}$ are correlated with the regressors in the fixed effects model. The value of rho .4133 reveals that $41.33 \%$ of the variance is explained due to the differences across panels in the sample undertaken.

The F-test is a test to see whether all the coefficients in the model are different than zero and it explains the goodness fit of the model. According to the table 5, the F-value 57.51 is statically significant at $1 \%$ level which indicates that an overall this model is goodness fit with the dependent and independent variables in this study.

Further, the overall $\mathrm{R}^{2}=0.4774$ indicates that nearly $48 \%$ of variance of debt ratio is explained by all five independent variables in the model.

\subsection{Random Effects Model}

In order to fulfil the loss of the degree of significance in the fixed effect, random effects model was developed. Random effect model contains that constant coefficiencies between the units do not differ. Under this random effect, individual effects of the companies are coincidental, assuming that the constant will be measured randomly in order to obtain unconsidered independent variables or the error (Bayrakdaroglu et al., 2013).

Table 6. The effect of explanatory variables on the debt ratio $\left(\mathrm{DR}_{\mathrm{it}}\right)$ using the random effects estimation model

\begin{tabular}{lllllll}
\hline DR & Coefficient. & Std. Err. & $\mathrm{z}$ & $\mathrm{P}>\mathrm{z}$ & [95\% Conf. & Interval] \\
\hline _Cons & -0.0475365 & 0.0998731 & -0.48 & 0.634 & -0.2432841 & 0.1482111 \\
SIZE & 0.0605756 & 0.0097893 & 6.19 & 0.000 & 0.0413889 & 0.0797623 \\
PROF & -0.2992748 & 0.0796453 & -3.76 & 0.000 & -0.4553767 & -0.1431729 \\
GROW & 0.0729099 & 0.0050474 & 14.44 & 0.000 & 0.063017 & 0.0828027 \\
TANG & 0.007618 & 0.0534348 & 0.14 & 0.887 & -0.0971122 & 0.1123483 \\
NDTS & -0.0640347 & 0.0584701 & -1.1 & 0.273 & -0.1786339 & 0.0505645 \\
\hline
\end{tabular}

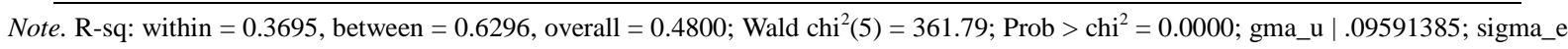
|.14036692; rho |.31829487; corr(u_i, X) = 0 (assumed).

The random effects estimation results are presented in Table 6, which indicates that firm size, profitability, and growth are significant while non-debt tax shield is insignificant. Further tangibility remained highly insignificant.

\subsection{Hausman Test}

In order to decide which one of the alternative panel analysis methods (fixed effects model and random effects model), hausman test has been used. The main difference between random effects and fixed effects is that fixed effects permits for correlation between unobserved effects and the explanatory variables while random effects needs these to be uncorrelated.

The Hausman test refers to the difference in the coefficient of the output obtained in fixed effects and random effects. The Hausman test has two restrictions, it requires strict exogeneity of error term and assumes that both idiosyncratic error and unobserved effects have constant variances (Baltagi, 2005).

The Hausman test assesses the uniqueness of the error term whether they are correlated with the response variable and the null hypothesis is that they are not correlated. Related to this, $\mathrm{H}_{0}$ hypothesis claims that "random effect exists" and $\mathrm{H}_{1}$ hypothesis declare that "random effects do not exist". 
Table 7. Hausman specification test results

Test: Ho: difference in coefficients not systematic

\begin{tabular}{lcccc}
\hline & $(\mathrm{b})$ & $(\mathrm{B})$ & $(\mathrm{b}-\mathrm{B})$ & sqrt(diag(V_b-V_B $))$ \\
& fixed & random & Difference & S.E. \\
\hline SIZE & 0.0615993 & 0.0605756 & 0.0010237 & 0.0059679 \\
PROF & -0.2707124 & -0.2992748 & 0.0285624 & 0.0337257 \\
GROW & 0.0680292 & 0.0729099 & -0.0048806 & 0.0010226 \\
TANG & 0.0097144 & 0.007618 & 0.0020964 & 0.0492845 \\
NDTS & -0.0518281 & -0.0640347 & 0.0122066 & 0.0061569 \\
\hline
\end{tabular}

Note. $\mathrm{chi}^{2}(5)=(\mathrm{b}-\mathrm{B})^{\prime}\left[\left(\mathrm{V} \_\mathrm{b}-\mathrm{V} \_\mathrm{B}\right)^{\wedge}(-1)\right](\mathrm{b}-\mathrm{B})=35.17 ;$ Prob $>\mathrm{chi}^{2}=0.0000$.

The Hausman specification test results from the above table shows that $\mathrm{H}_{0}$ hypothesis is rejected for leverage models with the significance level of one percent. Therefore, it may be better off employing the estimation of the fixed effects model. Thus, the panel data regression was analysed by the fixed effects model in this study.

\subsection{Robust Standard Error}

Balagi (2005) suggests to use the robust standard error to correct for heteroskedasticity since variance of the error term differs across the observations. The model needs to be corrected for hateroskedasticity failing with standard errors of the estimates being biased. Hateroskedasticity makes estimators not efficient because the estimated variances and covariance of the coefficients are biased and inconsistent and thus tests of hypotheses are no longer valid. The following table 4.8 shows the fixed effects model with robust standard error.

Table 8. Robust standard error

\begin{tabular}{ccccccc}
\hline DR & Coef. & Robust Std. Err. & $\mathrm{t}$ & $\mathrm{P}>\mathrm{t}$ & {$[95 \%$ Conf. } & Interval] \\
\hline Cons & -.064223 & 0.1617731 & -0.40 & 0.693 & -0.3885586 & 0.2601125 \\
SIZE & .0615993 & 0.0113622 & 5.42 & 0.000 & 0.0388195 & 0.0843792 \\
PROF & -.2707124 & 0.1295639 & -2.09 & 0.041 & -0.5304723 & -0.0109525 \\
GROW & .0680292 & 0.0141362 & 4.81 & 0.000 & 0.0396879 & 0.0963706 \\
TANG & .0097144 & 0.1410204 & 0.07 & 0.945 & -0.2730145 & 0.2924433 \\
NDTS & -.0518281 & 0.0862406 & -0.60 & 0.550 & -0.2247301 & 0.1210739 \\
\hline
\end{tabular}

Note. $\mathrm{R}$-sq: within $=0.3698$, between $=0.6227$, overall $=0.4774 ; \mathrm{F}(5,54)=35.45 ;$ Prob $>\mathrm{F}=0.0000$.

The fixed effect methodology, when corrected hateroskedasticity problem, provides the same set of coefficients but also a very similar set of $\mathrm{p}$-values. Table 8 shows that the level of significance of the explanatory variables displayed to affect leverage is the same in the fixed effects methodology, and the robust standard error. These results clearly state that even though the model is affected by heteroskedasticity, it does not impact on the set empirical results observed.

Finally, in addition to the above robust standard error, the Table 9 shows that the cluster robust standard error method is used which control for unknown heteroskedasticity within panel autocorrelation.

Table 9. Cluster robust standard error

\begin{tabular}{ccccccc}
\hline DR & Coef. & Robust Std. Err. & $\mathrm{t}$ & $\mathrm{P}>\mathrm{t}$ & [95 \% Conf. & Interval] \\
\hline _Cons & -.064223 & 0.1617731 & -0.40 & 0.693 & -0.3885586 & 0.2601125 \\
SIZE & .0615993 & 0.0113622 & 5.42 & 0.000 & 0.0388195 & 0.0843792 \\
PROF & -.2707124 & 0.1295639 & -2.09 & 0.041 & -0.5304723 & -0.0109525 \\
GROW & .0680292 & 0.0141362 & 4.81 & 0.000 & 0.0396879 & 0.0963706 \\
TANG & .0097144 & 0.1410204 & 0.07 & 0.945 & -0.2730145 & 0.2924433 \\
NDTS & -.0518281 & 0.0862406 & -0.60 & 0.550 & -0.2247301 & 0.1210739 \\
\hline
\end{tabular}

The fixed effect methodology, when corrected hateroskedasticity with in panel autocorrelation problem, offers the similar set of coefficients as well as the same set of p-values. At the end of this analysis, Table 9 shows that the level of significance of the explanatory variables exhibited to affect leverage is the similar in the fixed effects methodology, and the cluster robust standard error. 


\section{Conclusion}

This study objective is that to define which firm certain factors are determinants on the capital structure and which of the existent capital structure theories are explanatory for the emergent market of Sri Lanka. The fixed effect regression reveals that firm size, profitability and growth show a statistically significant impact on total debt. It can be reported that firm specific factors paly an important role in concerning the capital structure of the Sri Lankan Listed companies.

Specifically, it can be argued that bigger Sri Lankan companies are willing to have higher debt ratio rather than the small Sri Lankan companies. Further, profitable Sri Lankan companies prefer to have less debt in their capital structure. The Sri Lankan companies which have high growth may have high debt ratio.

Profitability and growth variables ratify the pecking order theory though firm size confirms the trade-off theory. Furthermore, tangibility and non-debt tax shield have no significant relation on total debt. Even though coefficient for tangibility and non-debt tax shield confirms the trade-off theory.

While interpreting the results of the variance decomposition, it can be concluded that the firm-fixed effect is the most important contributor to the explanatory power of various specifications, greatly exceeding that of the traditional determinants. This confirms that most of the explanatory power of previous identified determinants stems from cross sectional variation, which is removed by using fixed effects.

Ultimately, the outputs of this empirical study shows that there was strong evidence to support the pecking order theory by manufacturing based companies on the relevant determinant of profitability variable, and growth variable also strongly support to the implication of the pecking order theory. However, trade-off theory also can not be rejected because of the right prediction of the positive sign of size variable of manufacturing based companies. Hence, it could be concluded that implementation of pecking order theory is more appropriate to Sri Lankan context. This evidence is more consistent with the studies in other countries, such as Australian and Turkish companies which confirm the pecking order theory in their capital structure. Even though the research results are subject to various analytical methods, different time period, and different type of the sample used.

\section{References}

Abbad, K. B., \& Zaluki, N. A. A. (2012). The determinants of capital structure of Qatari listed companies. International Journal of Academic Research in Accounting, Finance and Management Sciences, 2, 93-108.

Abor, J. (2007a). Debt policy and performance of SMEs: Evidence from Ghanaian and South African firms. The Journal of Risk and Finance, 8, 364-379. http://dx.doi.org/10.1108/15265940710777315

Abor, J. (2007b). Industry classification and the capital structure on Ghanaian SMEs. Studies in Economics and Finance, 24, 207-219. http://dx.doi.org/10.1108/10867370710817392

Abor, J., \& Biekpe, N. (2009). How do we explain the capital structure of SMEs in Sub-Saharan Africa? Journal of Economic Studies, 36, 83-97. http://dx.doi.org/10.1108/01443580910923812

Akhtar, S. (2005). The determinants of capital structure for Australian multinational and domestic corporations. Australian Journal of Management, 30, 321-341. http://dx.doi.org/10.1177/031289620503000208

Al-Ajmi, J., Hussain, H. A., \& Al-Saleh, N. (2009). Decisions on capital structure in a Zakat environment with prohibition of riba: The case of Saudi Arabia. The Journal of Risk and Finance, 5, 460-476. http://dx.doi.org/10.1108/15265940911001376

Al-Najjar, B., \& Tayer, P. (2008). The relationship between capital structure and ownership structure. Managerial Finance, 34, 919-933. http://dx.doi.org/10.1108/03074350810915851

Ameer, R. (2013). Financial liberalization and firms' capital structure adjustments evidence from Southeast Asia and South America. Journal of Economics and Finance, 37, 1-32. http://dx.doi.org/10.1007/s12197-010-9158-3

Amidu, M. (2007). Determinants of capital structure of banks in Ghana: An empirical approach. Baltic Journal of Management, 2, 67-79. http://dx.doi.org/10.1108/17465260710720255

Antoniou, A., Guney, Y., \& Paudyal, K. (2008). The determinants of capital structure: Market-oriented versus Bank-oriented institutions. Journal of Financial and Quantitative Analysis, 43, 59-92. http://dx.doi.org/10.1017/S0022109000002751

Baltagi, B. H. (2005). Econometric analysis for panel data (3rd ed.). England: John Wiley \& Sons Ltd.

Bayrakdaroglu, A., Ege, I., \& Yazici, N. (2013). A panel data analysis of capital structure determinants: 
Empirical results from Turkish capital market. International Journal of Economics and Finance, 5, 131-140. http://dx.doi.org/10.5539/ijef.v5n4p131

Buvanendra, S. (2013). Capital structure determinants: Evidence from manufacturing and services sector companies in Sri Lanka. Academicia, 3(8), 83-99.

Chiang, Y. H., Cheng, E. W. L., \& Lam, P. T. I. (2010). Epistemology of capital structure decisions by building contractors in Hong Kong. Construction Innovation, 10, 329-345. http://dx.doi.org/10.1108/14714171011060105

Coleman, A. K. (2007). The impact of capital structure on the performance of microfinance institutions. The Journal of Risk Finance, 8(1), 56-71. http://dx.doi.org/10.1108/15265940710721082

Cortes, J. G., Valencia, J. B., \& Mercado, O. A. E. (2011). Capital structure in the manufacturing industry in Mexico. Advances in Competitiveness Research (ACR), 19, 3-16.

De Zoysa, A., Manawaduge, A. S., \& Chandrakumara, A. (2009). Profitability analysis of listed manufacturing companies in Sri Lanka and Malaysia: An empirical investigation. 4th Asian Academy of Applied Business Conference, pp. 34-43.

DeAngelo, \& Masulis. (1980). Optimal capital structure under corporate and personal taxation. Journal of financial economics, 8, 3-29. http://dx.doi.org/10.1016/0304-405X(80)90019-7

Eldomiaty, T. I. (2007). Determinants of corporate capital structure: Evidence from an emerging economy. International Journal of Commerce and Management, 17, 25-43. http://dx.doi.org/10.1108/10569210710774730

Eriotis, N., Vasiliou, D., \& Neokosmidi, Z. V. (2007). How firm characteristics affect capital structure: An empirical study. Managerial Finance, 33(5), 321-331. http://dx.doi.org/10.1108/03074350710739605

Faris, M., \& Mouamer, A. (2011). The determinants of capital structure of Palestine-listed companies. The journal of Risk and Finance, 12, 226-241. http://dx.doi.org/10.1108/15265941111136969

Fauzi, F., Basyith, A., \& Idris, M. (2013). The determinants of capital structure: An empirical study of New Zealand-Listed firms. Asian Journal of Finance and Accounting, 5, 2-21. http://dx.doi.org/10.5296/ajfa.v5i2.3740

Forte, D., Barros, L. A., \& Nakamura, W. T. (2013). Determinants of capital structure of small and medium sized $\begin{array}{lllll}\text { Brazilian enterprises. Brazilian Administration } & \text { Review, } 10,369 .\end{array}$ http://dx.doi.org/10.1590/S1807-76922013000300007

Getzmann, A., Lang, S., \& Spremann, K. (2010). Determinants of the target capital structure and adjustment speed - Evidence from Asian, European and U.S.-capital markets. Working Paper, 1-30.

Gujarati, N., \& Porter, C. (2009). Basic Econometrics (5th ed.). America: McGrow-Hill companies, Inc.

Gurcharan, S. (2010). A review of optimal capital structure determinant of selected ASEAN countries. Journal of Finance and Economics, 47, 30-41.

Gwatidzo, T., \& Ramjee, A. (2012). Dynamics in Capital structure determinants in South Africa. Meditari Accountancy Research, 20, 4.

Janbaz, M. (2010). Capital structure decisions in the Iranian corporate sector. International Research Journal of Finance and Economics, 58, 24-31.

Lingesiya, Y. (2012). Factors influencing companies' leverage: Evidence from Sri Lankan panel data. South Asian Academic Research Journals, 2, 50-63.

Mallikarjunappa, T., \& Goveas, C. (2007). Factors determining the capital structure of Pharmaceutical Companies in India. The Icfai Journal of Applied Finance, 13, 56-72.

Miller, M. H. (1977). Debt and Taxes. The Journal of Finance, 32, 261-275.

Modigliani, F., \& Miller, M. (1958). The cost of capital, corporate finance and the theory of investment. American Economic Review, 48, 261-297.

Moosa, I., \& Li, L. (2012). Firm-specific factors as characteristics of capital structure: Evidence from Indonesia. Review of Pacific Basin Financial Markets and Policies, 15, 1-17. http://dx.doi.org/10.1142/S021909151150007X

Morri, G., \& Cristanziani, F. (2009). What determinants of capital structure of real estate companies? An analysis 
of the EPRA/NAREIT Europe index. Journal of Property Investment and Finance, 27, 318-372. http://dx.doi.org/10.1108/14635780910972288

Mukherjee, S., \& Mahakud, J. (2012). Are trade-off theory and pecking order theories of capital structure mutually exclusive? Journal of Management Research, 12, 41-55.

Myers, S. C. (1977). Determinants of corporate borrowing. Journal of Financial Economics, 5, 147-175. http://dx.doi.org/10.1016/0304-405X(77)90015-0

Myers, S. C. (1984). The Capital structure puzzle. The journal of Finance, 39, 575-592. http://dx.doi.org/10.2307/2327916

Noulas, N., \& Genimakis, G. (2011). The determinants of capital structure choice: Evidence from Greek listed companies. Applied Financial Economics, 21, 379-387. http://dx.doi.org/10.1080/09603107.2010.532108

Ooi, J. (1999). The determinants of capital structure: Evidence on UK property companies. Journal of Property Investment and Finance, 17, 464-480. http://dx.doi.org/10.1108/14635789910294886

Pratheepkanth, P. (2011). Capital structure and financial performance. Researchers World, 2, 172-183.

Qiu, M., \& La, B. (2010). Firm characteristics as Determinants of capital structure in Australia. International journal of the Economics of Business, 17, 277-287. http://dx.doi.org/10.1080/13571516.2010.513810

Rajan, R. G., \& Zingales, L. (1995). What do we know about capital structure: Some evidence from international data. Journal of Finance, 50, 1421-1460. http://dx.doi.org/10.1111/j.1540-6261.1995.tb05184.x

Samarakoon, L. P. (1999). The capital structure of Sri Lankan companies. Sri Lankan Journal of Management, 4, 18-30.

Sangeetha, \& Sivathaasan. (2013). Factors determining capital structure: A case study of listed companies in Sri Lanka. Research Journal of Finance and Accounting, 4, 236-247.

Santi, F. (2003). Determinants of Indonesian firms' capital structure: Panel data analysis. Jurnal Ekonomi Dan Bisnis Indonesia, 18, 243-260.

Serrasqueiro, Z. M. S., \& Rogao, M. C. R. (2009). Capital structure of listed Portuguese companies: Determinants of debt adjustment. Review of Accounting and Fiance, 8, 54-75. http://dx.doi.org/10.1108/14757700910934238

Sheikh, N. A., \& Wang, Z. (2011). Determinants of capital structure: An empirical study of firms in manufacturing industry of Pakistan. Managerial Finance, 37, 117-133. http://dx.doi.org/10.1108/03074351111103668

Smith, G. P. (2012). Capital structure determinants for tax-exempt organizations: Evidence from the UK. $\begin{array}{llll}\text { Financial Accountability } & \text { and }\end{array}$ http://dx.doi.org/10.1111/j.1468-0408.2012.00540.x

Titman, S., \& Wessels, R. (1988). The determinants of capital structure choice. The Journal of Finance, 43, 1-19. http://dx.doi.org/10.1111/j.1540-6261.1988.tb02585.x

Upneja, A., \& Michael. (2001). An examination of capital structure in the restaurant industry. International Journal of Contemporary Hospitality of Management, 54-59. http://dx.doi.org/10.1108/09596110110381825

Voulgaris, F., Asteriou, D., \& Agiomirgianakis, G. (2004). Size and Determinant of capital structure in the Greek manufacturing firms. International Review of Applied Economics, 18, 247-262. http://dx.doi.org/10.1080/0269217042000186714

Wald, J. K. (1999). How firm characteristics affect capital structure: An international comparison. The Journal of Financial Research, 22(2), 161-187. http://dx.doi.org/10.1111/j.1475-6803.1999.tb00721.x

Wiwattanakantang, Y. (1999). An empirical study on the determinants of the capital structure of Thai firms. Pacific-Basin Finance Journal, 7, 371-403. http://dx.doi.org/10.1016/S0927-538X(99)00007-4

\section{Copyrights}

Copyright for this article is retained by the author(s), with first publication rights granted to the journal.

This is an open-access article distributed under the terms and conditions of the Creative Commons Attribution license (http://creativecommons.org/licenses/by/3.0/). 